Administrative Issues Journal: Connecting Education, Practice, and Research, Winter 2017, Vol. 7, No. 2: 23-46. DOI: 10.5929/2017.7.2.5

\title{
Classical literature gives life to business paradox and systems integration
}

\author{
Robert A. Page, Ph.D. \\ Samuel K. Andoh, Ph.D. \\ Robert A. Smith, J.D., \\ Southern Connecticut State University
}

\begin{abstract}
Professors bemoan the great difficulty students have understanding the complexity of their disciplines or functional specializations. Many non-traditional students have work and family commitments that limit the time needed to reflect professionally and to master these concepts. This disconnect has persisted despite decades of work developing more integrated, interdisciplinary curricula. One potential, partial solution is to simply start sooner and partner with liberal arts courses to introduce business students to complexity and paradox before they arrive at the business school. Grounding these concepts in the Classics embeds them in great stories of passion, betrayal, commitment, and emotion normally absent in business courses. Business textbooks and cases are usually sanitized, simplified, and quantified, stripping them of the chaos normally experienced in reality. These classical tales are captivating and compelling, making the business concepts used to analyze them more memorable and hopefully retained until encountered again in the business curriculum. The classics deal with real and raw emotions, with powerful prose more likely to capture and engage students on a very personal level. This article explores how economics can be used to analyze Jane Austen's Pride and Prejudice, how multistakeholder theory can be used to analyze Sophocles' Antigone, and how business contract law can be used to analyze William Shakespeare's The Merchant of Venice. Liberal Arts programs will gain additional relevance, commanding further student respect; business schools will stand a better chance of meeting AACSB gold-standard, interdisciplinary learning outcomes when students are exposed to these concepts before arriving at the business school.
\end{abstract}

Keywords: business education, interdisciplinarity, complexity, paradox, classical literature

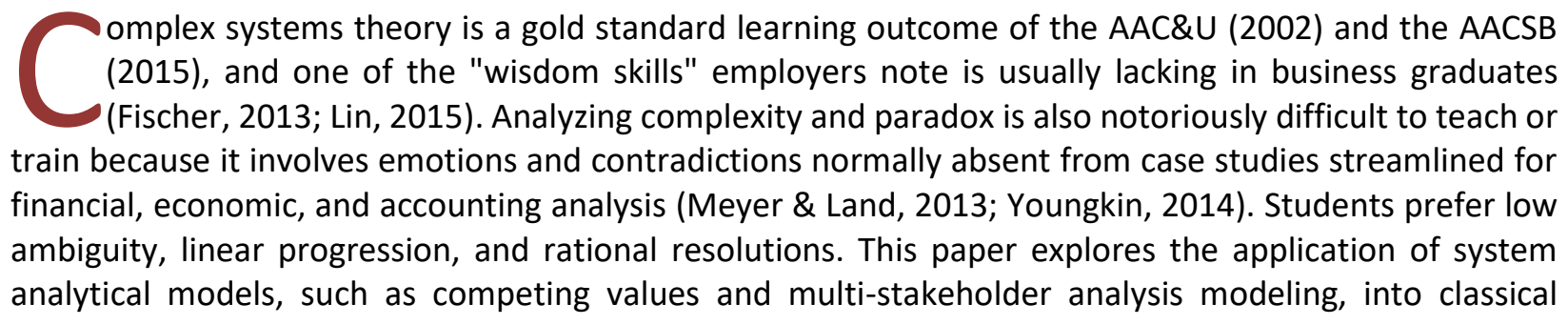

PAGE, ANDOH, \& SMITH / DOI: 10.5929/2017.7.2.5 
literature courses. The premise is that students who are engaged by the power of literature and apply systems models to understand it are more likely to retain and transfer that knowledge to subsequent business courses, increasing their understanding of complex systems theory and its real-world applications.

\section{Complexity and Paradox in Business}

Schumacher (1977) suggests that the world presents us with two fundamentally different types of problems: convergent and divergent problems. Convergent problems are quantifiable and can be resolved through empirical analysis. Divergent problems do not lend themselves to the constraints of logic or quantitative analysis. Here we enter the realm of metaphysics because researchers note that not only do divergent problems lack a single solution, but "the more rigorously and precisely they are studied, the more solutions tend to diverge, or become contradictory and opposite" (Cameron, 1986, p. 548; see also Battilana \& Casciaro, 2012; Bechara \& Van de Ven, 2011; Quinn, 1988, 2015). Thus, divergent problems are inherently contradictory. Excellent examples of divergent problems involve trying to identify the most effective way to manage, or the most effective way to lead others. While both topics have been extensively investigated, research has yielded more differences of opinion than any firm answers. Understanding the paradox and ambiguity inherent in divergent business problems becomes one of the most critical functions of management (Cameron, 1986; Jay, 2013; Quinn, 1988, 2015; Smith \& Lewis, 2011).

In Merriam Webster's Dictionary, paradox is defined as "a statement that is seemingly contradictory ... and yet is perhaps true." Slaatte (1968) elaborates:

A paradox is an idea involving two opposing thoughts or propositions which, however contradictory, are equally necessary to convey a more imposing, illuminating, life-related or provocative insight into truth than either factor can muster in its own right. What the mind seemingly cannot think it must think; what reason is reluctant to express it must express. (p. 4)

In the context of management, paradox means that organizations often possess characteristics that conflict and contradict each other, but also that these contradictions do not detract from organizational activity; rather, they may positively contribute to it (Cameron, 1986; Quinn, 1988, 2015). It is not unusual for managers to prefer both growth and stability, efficiency and flexibility, high capital investment and high returns to stockholders, autonomy and control, and so on (Battilana \& Casciaro, 2012; Bechara \& Van de Ven, 2011). "To be effective, an organization must possess attributes that are simultaneously contradictory, even mutually exclusive....because effectiveness is inherently tied to paradox, the construct of effectiveness can be understood only in a limited way without considering simultaneous contradictions" (Cameron, 1986, pp. 545, 549). While there may be consensus among many researchers and practitioners concerning the importance of the topic, most business programs focus on convergent problems, leaving the understanding of divergent problems for real-world experience and learning (Fischer, 2013; Pfeffer \& Fong, 2002).

\section{Business Education}

The question becomes: despite the difficulty in teaching complexity and paradox, is business education complete without it? Cameron concludes, "The principle of paradox being proposed suggests that disconfirmation, contradiction, and nonlinearity are inherent in all organizations, a direct contradiction of current models and theories" (1986, p. 549). For managers, K. E. Weick recommends, "Ambivalence is the 
optimal compromise, loose coupling promotes adaptation, ignorance is functional, everything flows, adaptation can preclude adaptability and things keep falling apart" (1979, p. 120; see also Weick 1995; Weick, Sutcliffe \& Obstfeld, 2005). As industry environments have become unstable and rapidly changing, business education stakeholders agree on the power of thinking critically about paradoxes.

In general, there is emerging consensus among stakeholders concerning the critical skills and understanding college and university students should retain from business programs. Table 1 compares the results of a comprehensive research summary (Kuh, 2008), an empirical study of common outcomes in business programs (Moskal, Taylor, \& Keon, 2008), corporate recruiter priorities (Hart Research, 2013; Safon, 2007); and a comprehensive forecasting model of future work skills (Davies, Fidler, \& Gorbis, 2011).

Table 1

Comparative Business Learning Outcomes

\begin{tabular}{|c|c|c|c|}
\hline $\begin{array}{c}\text { Essential } \\
\text { Undergraduate } \\
\text { Learning Outcomes }\end{array}$ & $\begin{array}{l}\text { Common Bus. School } \\
\text { Learning Outcomes }\end{array}$ & $\begin{array}{l}\text { Recruiter } \\
\text { Priorities }\end{array}$ & $\begin{array}{c}\text { Future Forecasted } \\
\text { Skills }\end{array}$ \\
\hline $\begin{array}{l}\text { Written/oral } \\
\text { communication } \\
\text { Teamwork and } \\
\text { problem-solving }\end{array}$ & $\begin{array}{c}\text { Communication } \\
\text { Group/individual } \\
\text { dynamics; } \\
\text { Motivation }\end{array}$ & $\begin{array}{l}\text { Communication } \\
\text { Interpersonal skills/ } \\
\text { Teamwork } \\
\text { Org. culture fit }\end{array}$ & $\begin{array}{c}\text { Social intelligence } \\
\text { (ability to connect with } \\
\text { others) } \\
\text { New-media literacy } \\
\text { Virtual collaboration }\end{array}$ \\
\hline $\begin{array}{l}\text { Knowledge of human } \\
\text { culture and } \\
\text { physical/natural world }\end{array}$ & $\begin{array}{c}\text { Global awareness } \\
\text { Diversity/multicultural }\end{array}$ & Intercultural skills & $\begin{array}{l}\text { Cross-cultural } \\
\text { competency }\end{array}$ \\
\hline $\begin{array}{l}\text { Personal and Social } \\
\text { responsibility }\end{array}$ & Ethical understanding & Ethics/integrity & \\
\hline $\begin{array}{l}\text { Integrative/applied } \\
\text { learning } \\
\text { Information literacy } \\
\text { Critical thinking } \\
\end{array}$ & $\begin{array}{l}\text { Organizational Skills } \\
\text { Leadership }\end{array}$ & $\begin{array}{l}\text { Well-rounded skills } \\
\text { Leadership potential } \\
\text { Strategic thinking }\end{array}$ & $\begin{array}{l}\text { Multidisciplinary } \\
\text { understanding } \\
\text { Sense-making }\end{array}$ \\
\hline Inquiry and analysis & $\begin{array}{l}\text { Analytical/statistical } \\
\text { Critical thinking }\end{array}$ & $\begin{array}{c}\text { Analytical/ } \\
\text { problem-solving } \\
\text { Critical thinking } \\
\end{array}$ & $\begin{array}{l}\text { A design mind-set } \\
\text { Cognitive load } \\
\text { management }\end{array}$ \\
\hline Quantitative literacy & MIS / IT & & Computational thinking \\
\hline $\begin{array}{c}\text { Creative/innovative } \\
\text { thinking }\end{array}$ & & $\begin{array}{l}\text { Continuous learning } \\
\text { Innovation }\end{array}$ & $\begin{array}{c}\text { Novel and adaptive } \\
\text { thinking }\end{array}$ \\
\hline
\end{tabular}

Part of the promise of business programs lies in training critical "soft" skills-such as ethical decisionmaking, communication (written and verbal), interpersonal skills, and creativity-and in broader "systems-thinking" skills, allowing for effective integration and organization across organizations (Atwater, Kanaan, \& Stephens, 2008; Bisoux, 2005; Davies, Fidler, \& Gorbis, 2011; Hart Research, 2013; 
Lin, 2015; Pfeffer \& Fong, 2002). Unfortunately, employer complaints target some of these same areas: "When it comes to the skills most needed by employers, job candidates are lacking most in written and oral communication skills, adaptability and managing multiple priorities, and making decisions and problem solving" (Fischer, 2013, p. 23). Leaders must cope with rapid changes in organizational structures, processes, and technologies, and those who are not reflexive about themselves and understanding of their coworkers (particularly in global, cross-cultural contexts) often create disastrous, dysfunctional tensions that undermine effectiveness (Christensen, 2013; Gharajedaghi, 2011; Hart, 2013; Hogan \& Warrenfeltz, 2003; Senge, 2004).

This paper focuses on the complexity part of this equation. Graduates have difficulty with an increasingly paradoxical business world full of uncertainty, turbulence, and change (Gharajedaghi, 2011; Lin, 2015; Tugend, 2013). This lack of understanding complexity threatens the success of business graduates who are in danger of becoming largely irrelevant to "real-world" management challenges (Fischer, 2013; Pfeffer \& Fong, 2002; Seybolt, 2004; Tugend, 2013). Most traditional MBA programs teach skills in conventional function silos, much like an assembly line, with the emphasis on finding and analyzing problems versus developing and implementing viable problem-solving strategies (Pfeffer \& Fong, 2002; Porter \& McKibbin, 1988, 2015; Shinn, 2004). This trend towards the professionalization of faculty into discrete academic disciplines with narrow specializations, even sub-specializations, has intensified (Atwater et al., 2008; Safon, 2007).

This specialized focus leaves little room for teaching reforms that could break down the barriers imposed by specialization, such as interdisciplinarity, multidisciplinarity and learning communities (Thompson \& Purdy, 2009). Thus, business students can be criticized as being superbly trained in skills that are, in many cases, difficult to apply to the needs of more complex and inter-related real-world business environments. Consequently, analysts note an increasing skepticism about the value of management education (Datar, Garvin, \& Cullen, 2011; Grey, 2004; Pfeffer \& Fong, 2002).

Best practices require integration, moving from presenting discrete knowledge packets and skill sets towards making explicit linkages and connections between and among academic specializations (Kuh, 2008; Smith \& Colby, 2007): "The role of business schools [in integration] remains underdeveloped, undervalued, and too-often unnoticed. To start, business schools will need to place even greater emphasis on interdisciplinary collaboration across university campuses, particularly with schools of engineering and sciences" (AACSB, 2015, p. 2). The emphasis of this "new vision" will be on recognizing relationships and linkages between disciplines, and developing students' abilities to systematically analyze and evaluate whatever knowledge and experiences they encounter later in life and work, even when these experiences do not neatly fit within conventional disciplinary differentiations.

The ultimate objective of interdisciplinarity is systems thinking-an outcome in demand by businesses, but routinely neglected by business schools (Atwater et al., 2008). Systems thinking focuses on the big picture, instead of specific functional specializations and discrete organizational systems. In contrast to typical managerial decision-making, systems thinking is holistic versus reductionist, synthetic versus analytic, and long-term versus short-term. Causality is explored as circular amplification loops, rather than just as a linear progression. Systems thinking is about overall effectiveness more than efficiency, about indirect, as well as direct consequences, about best value more than low cost, and explores alignment as a balancing act more than a problem-solving exercise (Atwater et al., 2008; Senge, 2006; Smith \& Lewis, 2011).

PAGE, ANDOH, \& SMITH / DOI: 10.5929/2017.7.2.5 
Unfortunately, the systematic integration of the broader interpersonal and analytical "wisdom" skills associated with the liberal arts and interdisciplinary approaches spanning the different functional areas of business (management, marketing, finance, accounting, etc.) is so problematic the goal has been adopted as an accreditation criterion for over a decade (AACSB, 2005, 2015; Chew \& McInnis-Bowers, 2004; Lin, 2015).

\section{Teaching Complexity}

Responding to this need, Robert Quinn pioneered a very successful textbook series teaching managerial skills through exploring paradox and competing values (Quinn et al., 2015). To master paradox, managers must apply the following principles:

- Think in terms of competing values, which are almost impossible to effectively pursue simultaneous, like quality versus speed, innovation versus efficiency, etc.

- Think in terms of systems and cycles. Complex systems have inevitable tension between different parts of that system that cannot simply be managed away, they simply will manifest in another way. As Senge (2004) notes, today's answers become the source of tomorrow's problems

- Avoid cognitive simplification strategies. "Schismogenic thinking," where the manager chooses a set of favorite values or principles, ignores the other aspects of the paradox, so contradiction is "defined away."

Quinn offers a three-step process to transcend paradox and develop a state of "creative tension," which fosters creativity and excellence:

Moving beyond rational management involves ... three steps. The first step is recognizing polarities. The second step is seeing the strength and the weakness in each of the polar perspectives. The third, and most challenging, step is not to affix to one or the other but to move to a metalevel that allows one to see the interpenetration and the inseparability of the two polarities. This third step takes us to a transformational logic. It allows for simultaneous integration and differentiation. (1988, pp. 164-165)

In both the classroom and board room, these principles are reinforced primarily through analytical systems approaches and case studies (Andriopoulos \& Lewis, 2009; Beech et al., 2004; Gandz \& Hayes, 1988; Smith \& Lewis, 2011; Sterman, 2000). However, managers and students still struggle with these unfamiliar concepts.

Beyond problems of high technical complexity and ambiguity caused by inadequate information, many divergent contexts are even more difficult to understand because they often involve social processes and human emotions that are fundamentally "arational," such as confusion, fear, and anxiety (Meyer \& Land, 2013; Quinn, 1988, 2015). Weick concludes: "emotions, searchings, frustrations, heat, fury, joy, delight, depression, and moodiness, all prominent enough parts of organizational life" are normally excluded in rational, quantitative models (Weick, 1979, p. 240; see also Weick 1995; Weick, Sutcliffe, \& Obstfeld, 2005). This is unfortunate, since motivation and meaning are heavily influenced by these emotional dimensions of our lives. While such subjective factors are very difficult to conceptualize and measure, eliminating them leaves people and their organizations lifeless, meaningless, and passionless:

Thinking must be anchored to experience, and the search for meaning must be geared to the source of meaning, namely, our passions - our emotions, our moods, our desires.... Emotions are

PAGE, ANDOH, \& SMITH / DOI: 10.5929/2017.7.2.5 
said to distort our reality; I argue that they are responsible for it. Emotions are said to divide us from our interests and our purposes. The emotions and consequently the passions in general are our reasons in life. What is called "reason" is the passions enlightened, "illuminated" by reflection and supported by a perspicacious deliberation that the emotions in their urgency normally exclude. (Solomon, 1976, p.15)

Emotion is but one of a number of important contextual variables, which are extremely difficult to quantitatively measure, and have enormous impact on how people feel and behave. Due to such limitations, some analysts concluded that to get an organization into a countable, measurable form is to strip it of what made it worth counting in the first place (Weick, 1979, 1995; Weick, Sutcliffe, \& Obstfeld, 2005). John Steinbeck illustrates this dilemma using descriptions of the Mexican Sierra, a mackerel-like fish with brilliant blue spots found in the Gulf of California:

The Mexican Sierra has 17 plus 15 plus 9 spines in the dorsal fin. These can easily be counted. But if the sierra strikes hard on the line so that our hands are burned, if the fish sounds and nearly escapes and finally comes in over the rail, his colors pulsing and his tail beating the air, a whole new relational externality has come into being-an entity which is more than the sum of the fish plus the fisherman. The only way to count the spines of the sierra unaffected by this second relational reality is to sit in a laboratory, open an evil-smelling jar, remove a stiff colorless fish from the formalin solution, count the spines, and write the truth.... There you have recorded a reality which cannot be assailed-probably the least important reality concerning either the fish or yourself. It is good to know what you are doing. The man with his pickled fish has set down one truth and recorded in his experience many lies. The fish is not that color, that texture, that dead, nor does he smell that way... we were determined not to let the passion for unassailable little truths draw in the horizon and crowd the sky down on us. We knew that what seemed to be true could only be relatively true anyway. There is no other kind of observation. (Steinbeck \& Ricketts, 1951, p. 31)

And nothing is quite as powerful at communicating the light and heat and passion of this arational side of business as literature. Edward W. Younkins notes: "Fiction, including novels, plays, and films, can be a powerful force to educate students and employees in ways that lectures, textbooks, articles, case studies, and other traditional teaching approaches cannot" (2014, p. ix).

\section{Paradox, Ethics, and Literature}

Historically, paradox and systems theory-particularly multi-stakeholder theory-have been used to explore social responsibility and business ethics in the classroom, sometimes using fiction and great literature so the student can personally relate to these ethically tormented characters (Gandz \& Hayes, 1988; Michaelson, 2015; Shepard, Goldsby \& Gerde, 1997). The alternative story-telling mediums, usually involving case studies, are all too often sanitized and rationalized to portray business situations that fit neatly into the convergent analyses of finance, accounting and economics-a "one-size-fits-all" approach to managing and leading (Badaracco, 2006; Pfeffder \& Fong, 2002).

What leaders struggle with usually comes down to ... the complex and often contradictory nature of human beings. No matter what processes, policies and structures businesses put in place, people remain complicated and unpredictable: we don't always get along; we have very diverse motivations; we find change painful and difficult; we don't always behave "rationally"; and we don't always do the right thing, even when we have every reason to do so. Much great literature

PAGE, ANDOH, \& SMITH / DOI: 10.5929/2017.7.2.5 
captures this acutely and provides us with texts that challenge and lay bare the simplistic ways we can so easily go wrong when we think about it. Insights from literature and the humanities are particularly valuable when trying to understand behavior that doesn't seem to make sense in a classic economic analysis. Examples of people being confusing in the world of business abound, whether dealing with colleagues, partners or customers. (Biriotti, 2013, p. 10)

Beyond ethics, literature captures some of the real-world chaos that forces managers to enhance selfunderstanding and recognize alternative perspectives and outside-the-box solutions (Leddy, 2013; Michaelson, 2015). Great literature tackles the challenges of organizational decision-making under conditions of high velocity change. While management science has developed a toolbox of organizational development and process re-engineering techniques, "they often fall short of providing satisfactory solutions, reducing people to 'stakeholders' or cogs in a machine" (Biriotti, 2013, p. 11). The emotional impact of relating to relatable characters helps prompt professional self-reflection and broader systemwide linkages, which otherwise tend to occur only after training or considerable experience on the job.

Students in my class react to characters in the book as if they're real people. There's a much deeper engagement in the actual material. It's not about whether the debits and credits add up. They're making comments about who they are and what they care about, and how they feel about the world that differs from their fellow students. It also reflects the student's own character and judgment. ... Literature helps identify the really complicated issues, and the stakes on all sides. (Badaracco, quoted by Leddy, 2013, p. 2)

Through the vicarious experience of literary characters, students experience chaos and uncertainty from a distance, avoiding the panic they would experience in real life. This allows them the luxury of being able to react vicariously and more rationally to threatening circumstances. Literature pushes them out of their comfort zone without creating such high levels of anxiety that they retreat behind illusions of control.

Illusions of control are socially-created cognitive simplification strategies which define paradox away when decision-makers need to treat high levels of uncertainty and chaos as controllable events (Carr \& Blettner, 2010). Illusion of control is defined as "an expectancy of a personal success probability inappropriately higher than the objective probability would warrant" (Langer, 1975). Perceptions of uncertainty and information overload must be managed. While moderate levels of uncertainty are uncomfortable, and high levels of uncertainty quickly become dysfunctional, all too often, uncertainty ends up displacing rationality in decision-making processes with recklessness, anger, fear, depression, or withdrawal. In their simplicity, superstition, socially valued norms, and popular fads provide valuable illusions of control, reaffirm expertise, reinforce a common mental map and language, and rally the troops to action (Jackson, 2001). In essence, these forecasts are management rituals to legitimize the power and authority of leaders, as well as the validity of their strategies, giving them an appearance of professionalism, and a basis for cooperation and coordination of activities, particularly in times of chaos.

Is there really any difference between a chief executive asking his strategic planners for scenarios for the future, and a Babylonian monarch making similar demands of his astrologer? We suspect not. Both may provide a basis for decision where there is no rational method ... But more importantly, both demonstrate that the leader is competent and knows how to do such things. (Gimpl \& Dakin, 1984, p.130)

Literature thwarts simplification strategies with context and rich detail and tragedy; Shakespeare's King Lear can teach the pitfalls of illusions of control and unintended consequences in leadership. The 
pedagogical hypothesis of this paper is that by introducing complex systems theory as a means to help understand the classics, students will be better able to understand how to apply it to critical business contexts and problems later on in classes in their major. The power of the classics will boost retention.

\section{Integrating Complexity and Classics}

Systems theory has produced powerful conceptual models that students and managers often employ to understand complexity and paradox.

\section{The Competing Values}

The competing value model captures the inherent paradox and inherent tensions involved in organizational effectiveness (Quinn \& Rohrbaugh, 1983; Quinn, 1988, 2015). The premise is that organizations, groups, and people never resolve these creative tensions between extremes; they merely choose their position along each continuum. The classic competing values framework focuses on private sector organizations and the major schools of academic thought that evolved to study them. A simplified competing values model is illustrated in Figure 1.

Figure 1: Competing Values Framework

\begin{tabular}{cc|c} 
& \multicolumn{2}{c}{ Control } \\
\cline { 2 - 3 } $\begin{array}{c}\text { Internal } \\
\text { Focus }\end{array}$ & $\begin{array}{c}\text { Internal Process Model } \\
\text { (Communication, MIS, } \\
\text { services, order) }\end{array}$ & $\begin{array}{c}\text { Rational Goal Model } \\
\text { (planning, productivity, } \\
\text { efficiency) }\end{array}$ \\
\cline { 2 - 3 } (teamwork, unity, networking) & $\begin{array}{c}\text { Open systems Model } \\
\text { (learning, partnering, } \\
\text { initiative, growth) }\end{array}$ \\
Flexibility $\quad$ Focus
\end{tabular}

Once the continua are established, label each quadrant and see if the quadrants created are conceptually plausible and have valuable explanatory power. This model can be adapted for any major issue and any major industry or market. All that is necessary is to identify two competing values continua to anchor the horizontal and vertical continua. These can represent major controversies, paradigms, or objectives that conflict instead of complement each other. Opportunities to apply this model in great literature abound; this also represents a critical managerial skill in handling complexity and paradox on the job.

Antigone, by Sophocles, provides an ideal vehicle to explore leadership and the unintended consequences of policy. In the play, two Princes, Eteocles and Polynices, are sharing the rule of the kingdom after the death of their father. When Eteocles gets power-hungry, Polynices makes alliances with six foreign powers and attacks. The attack fails, but leaves both princes dead, so the kingdom passes to Creon, their uncle. Horrified by Polynices' foreign alliances, Creon orders his body to be left to rot publicly, as a warning of the consequences of betrayal, which seems warranted under the circumstances. Creon is an old, experienced hand at leadership, and is determined to restore order out of this chaos through sets of laws and social structures that will be enforced, some on pain of death. This is the reaction of many business leaders to high levels of uncertainty and change - double-down on what has worked in the past and escalate commitment.

Thus, Antigone sets the stage for a classic conflict of competing values - the tradeoff between control, embodied in formal structures, policies, and organizational systems (the internal process model), and 
individual creativity, expression and conscience (the human relations model). Formal controls, when implemented correctly, enable and foster flexibility, adaptation, and change (Wilden et al., 2013; Miles, et al., 1978). When formal controls are too tight they become stifling and undermine individual creativity, innovation and risk-taking-foundations of an effective and sustainable organization (Adler \& Borys, 1996). On the other hand, rampant individuality leads to organizational chaos; it undermines collaboration and results in waste, undermining sustainability. Mix into this brew a touch of egotism and a stubborn tendency to escalate commitment to stay-the-course, and you have the root cause of many an organizational failure (Drummond, 2014). All in ancient Greece.

Enter Antigone, the sister of Polynices, a willful, rebellious princess who defies limits and holds convention in contempt. In business, these leaders are the arrogant, but sometimes inspired "cowboy entrepreneurs" who live to break the molds, impose their will on the universe, and see if this generates lasting change and innovation. Antigone decides to bury her brother, breaking with her proper role and defying conventions (formal internal processes), despite the risk of execution. Ismene, the dutiful sister, portrayed as beautiful and radiant in every way-the object of all men's admiration and desire-is horrified and pleads with her sister to conform, to no avail. These issues of just and unjust policies, of work/life balance and responsibilities, and of the costs of conformity, are all too real on the job in modern life.

Creon is angry, and quickly discovers Antigone buried her brother. However, when Antigone refuses to apologize, Creon feels trapped with no alternative but to enforce policy and execute his niece. Brutality is often the price of inflexibility, both in politics and business. Ismene is so devastated by the loss of all her brothers and sister that she commits suicide. Similarly, many of the best and brightest will exit a business when the stress of these kinds of power plays becomes too great, stripping the organization of its future. Creon is left with has no future and no heir. Everyone he cares for is dead, and the play ends with him surrounded by callous guards who maintain order for money, and do not care about anything but their own interests.

This is the central premise of competing values - tensions between opposites are a continuum and can seldom be resolved. If one end of the continuum-such as Creon's need for order-is arbitrarily enforced-over Antigone's need for filial loyalty and flexible policy-this imbalance can explosively manifest itself in extremely dysfunctional and tragic ways. The competing values model captures these dynamics well, as illustrated in Figure 2.

Biriotti advocates using Antigone for business students, and concludes:

When we read Sophocles' Antigone for instance, we are forced to see different points of view and to hold separate, even contradictory, positions in our mind simultaneously. In this classic battle of wills, the confrontation between conscience and power, we cannot resort to oversimplifications. The language won't let us. Nor will the centuries of tradition of scholarship that have kept the Antigone debates burning. And that is why in those ancient verses, we may not find answers, but perhaps a better way to remember how complex the question is. How does all this come to life in practice? This is no easy task. I have lent the major portion of my professional life to the struggle to find ways to do justice to both human complexity and the need for profit; to the importance of asking better and more rounded questions and the need to feed continually the inexorable and understandable appetite that businesses have for answers. (2013, p. 12)

PAGE, ANDOH, \& SMITH / DOI: 10.5929/2017.7.2.5 
Figure 2: Competing Values in Antigone

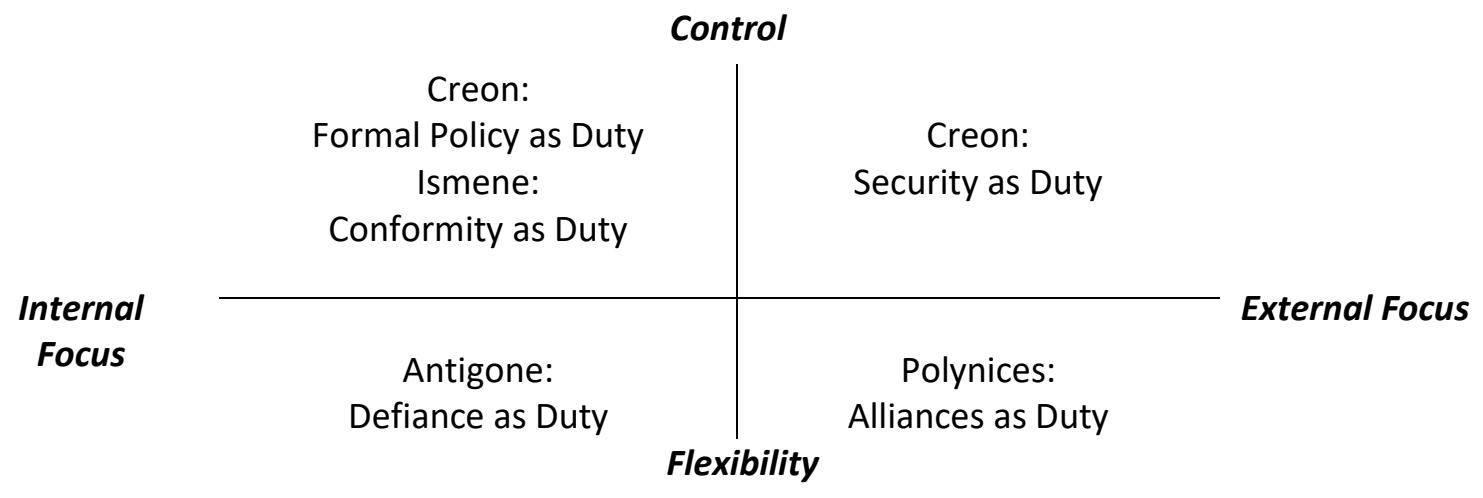

\section{Multi-Stakeholder Approach}

Stakeholder analysis focuses on identifying the commonalities and differences between all major internal and external stakeholders involved in a policy or decision process:

Stakeholder analysis is a tool for clearly defining key stakeholders for a project or other activity, understanding where stakeholders stand, and developing cooperation between the stakeholders and the project team. The main objective is to ensure successful outcomes for the project or the changes to come. (ASQ, 2015, p. 1)

Careful stakeholder analysis is essential for a comprehensive risk analysis. The degree to which stakeholders communicate and cooperate to achieve common interests determines the levels of conflict or collaboration to be anticipated. When differences are too great, groups of stakeholders form coalitions to influence the decision process positively or negatively. Anticipating and influencing these dynamics is critical for managerial effectiveness (ASQ, 2015; Plastrik, Taylor, \& Cleveland, 2014).

Balanced stakeholder theory argues that by respecting the legitimate rights and needs of the major stakeholders, conflict can be avoided, and overall effectiveness can be improved (Kaplan \& Norton, 1996; Niven, 2014). Focusing on one stakeholder group (such as owner/investors) at the expense of other shareholder groups (such as customers and employees), offers short-term advantages, but longer-term losses in loyalty, commitment, communication and innovation.

Jane Austen's Pride and Prejudice epitomizes complex stakeholder relationships with economic implications, involving income, income distribution, land as an index of social status and power, price index, wealth, standard of living, the structure of the economy, etc. The mix of economics and love could be of tremendous benefit in understanding how economic concepts are not so dry and arcane. On the surface, it appears that Pride and Prejudice (P\&P) is simply about love and marriage and social class, both of which are grounded in economics and finance (Chamberlain, 2014). At the core however, is the issue of overlapping intergenerational intertemporal utility maximization. It is also an excellent study in advanced economic game theory (Ellingsen \& Johannesson, 2008). The basic economic models useful for discussion with undergraduates involve income-based economic class, and currency exchange rates and valuation over time, all concepts critical for both economics and international business.

In a society in which only males could inherit birthrights, a family full of single women was an economic disaster. With perfect foresight, Mr. Bennet would have saved enough from his income to ensure that in 
the probable event that he did not have a son, his wife and daughters would not live in poverty. In the absence of a social safety net, such as old age, survivor and disability insurance (OASDI) or social security, which did not exist, he could also have bought a life insurance product that paid off enough upon his death so that his female heirs and surviving wife could live comfortably. But those were the signs of the times. Instead, Mr. Bennet bet that he would have a son.

Let us examine the rationale of this decision with a little foray into probabilities. The probability that all his five children would be girls is very low: actually only .03. It can be represented symbolically as follows: $\left[P\left(\right.\right.$ Girl) ${ }^{*} P\left(\right.$ Girl) $* P\left(\right.$ Girl) $* P\left(\right.$ Girl) ${ }^{*} P($ Girl) where $P$ stands for probability and the $P($ Girl) $=.5$ (hence the calculation $\left..5^{*} .5^{*} .5^{*} .5^{*} .5 .=.03\right)$. It also follows that the probability of having at least one boy among the five children is .97, (1-.03): quite high. The odds were clearly in Mr. Bennet's favor. With such a high probability of having at least one boy, Mr. Bennet was probably correct in assuming his estate would not bypass his heirs and go onto Mr. Collins, his cousin. There is only one problem. No matter how small the probability is, the utility or rather disutility of not having a boy is so high that in a rational world he should have thought about it and planned for it, unless of course the altruistic bequest motive for females was of no importance to him. Without belaboring the point, we buy property insurance, such as car insurance, despite never having had a car accident. If an event is possible, it has a probability of occurring; if it does occur, the consequences can be disastrous. The probability of an event occurring may be small but, as Mr. Bennet found out (mercifully, not to his chagrin) you can have five children and they can all be girls.

This is what makes the story so compelling, driving the plots and subplots, the intrigues and antagonisms exhibited in the novel. How can a family with little or no wealth to bequeath to five daughters when the estate is entailed to male heirs, of which the parents have none? How can Mr. Bennet ensure that his wife and daughters will not be reduced to poverty upon his death? First, we need to understand the economics of social class. See Table 2, "The Economics of Social Class: Class Structure in Austen's Britain Compared to Modern-day U.S."

The next challenge is to understand old English money. How much is $f 10,000.00$ today? Heldman (1990) estimates it at $\$ 331,300$ in 1988 dollars. First, one must find the prevailing exchange rate between the pound and the dollar to convert the pounds into dollars. Then, one must use the price index to convert the dollar equivalent of $£ 10,000.00$ into 1988 dollars or any year's dollars. For example, in 2016 US dollars, the Jane Austen $£ 10,000.00$ is worth $\$ 700,000$. The depreciated dollar truly "ain't worth a dime." This is a good point to talk about the effect of inflation: needing more money to buy the same "basket" of goods and services. Without a cost of living adjustment (COLA), if one's income remains the same over time, the ability to buy the same basket of goods bought in earlier years will be diminished, and one will be reduced to poverty.

Now we can understand the story much better. Landed gentry took the income from their land (rents, leases, etc.) and invested it in government securities (much safer, almost guaranteed returns and repayment of principal upon maturity; secured bonds), and lived off the proceeds $-4 \%$, to a maximum of $5 \%$ interest annually. However, only males in the family could inherit the estate and the interest (income) from the bonds. Inheritable wealth for women consisted of monetary savings, jewelry, and the like. So, to revisit the class structure. See Table 3, "The Breakdown and Distribution of Wealth according to Class: Austen's Britain Compared to Modern-day U.S."

PAGE, ANDOH, \& SMITH / DOI: 10.5929/2017.7.2.5 


\section{Table 2}

The Economics of Social Class: Class Structure in Austen's Britain Compared to Modern-day U.S.

\begin{tabular}{|c|c|}
\hline Colquhoun (1814) Austen's Britain & Thompson \& Hickey 2005 USA \\
\hline $\begin{array}{l}\text { Highest Orders: comprising } .01 \text { percent of the } \\
\text { population-members of the royal family }\end{array}$ & $\begin{array}{l}\text { Rich Capitalist class (1\%): Top-level executives, } \\
\text { celebrities, heirs: income of } \$ 500,000+\text { common. } \\
\text { Educated at the best schools }\end{array}$ \\
\hline $\begin{array}{l}\text { Lords: included spiritual and temporal and other } \\
\text { great offices of the state } \\
\text { Second Class: comprised of baronets, knights, } \\
\text { country gentlemen and others with large incomes }\end{array}$ & $\begin{array}{l}\text { Professional Upper middle class (15\%): } \\
\text { Professionals usually with graduate degrees or } \\
\text { best in class experience and expertise, earning } \\
\text { approximately } 100 \mathrm{~K}\end{array}$ \\
\hline $\begin{array}{l}\text { Third Class: comprised of clergy, doctors, } \\
\text { merchants, manufacturers on large scale and } \\
\text { bankers }\end{array}$ & $\begin{array}{l}\text { Lower middle class ( } 30 \%) \text { : Semi-professionals and } \\
\text { craftsmen. Most have some college education } \\
\text { and are white-collar. Approximate income range } \\
\text { is } 30 \text { to } 80 \mathrm{~K}\end{array}$ \\
\hline $\begin{array}{l}\text { Fourth Class: included lesser clergy, doctors, } \\
\text { lawyers, teachers, ship owners, merchants, and } \\
\text { manufacturers of the second class, as well as } \\
\text { shopkeepers, artists, builders, mechanics, and } \\
\text { persons of moderate income }\end{array}$ & $\begin{array}{l}\text { Working class (32\%): Clerical, pink- and blue- } \\
\text { collar workers, with no more than associates } \\
\text { degree education and limited job security; } \\
\text { common household incomes range from \$16 to } \\
\text { \$30k }\end{array}$ \\
\hline $\begin{array}{l}\text { Fifth Class: included lesser freeholders, } \\
\text { shopkeepers, innkeepers, publicans, persons of } \\
\text { miscellaneous occupations } \\
\text { Sixth Class: had working merchants, artists, } \\
\text { craftsmen and agricultural laborers }\end{array}$ & $\begin{array}{l}\text { Working poor (13\%): Service, low-rung clerical } \\
\text { and some blue-collar workers with some high } \\
\text { school education. High economic insecurity and } \\
\text { risk of poverty }\end{array}$ \\
\hline $\begin{array}{l}\text { Seventh Class: included paupers, vagrants, and } \\
\text { idle persons supported by criminal activities }\end{array}$ & $\begin{array}{l}\text { Poor Underclass (12\%) Those with limited or no } \\
\text { participation in the labor force. Reliant on } \\
\text { government transfers }\end{array}$ \\
\hline
\end{tabular}




\section{Table 3}

The Breakdown and Distribution of Wealth according to Class: Austen's Britain Compared to Modern-day U.S.

\begin{tabular}{|c|c|}
\hline un (1814) Austen's Britain & Thompson \& Hickey 2005 USA \\
\hline $\begin{array}{l}\text { Highest Orders and Second Class: } \\
\text { Bennet family annual income is } £ 2,000 \text { or } 140 \mathrm{~K} \\
\text { US - to Mr. Collins upon father's death; } \\
\text { Mr. Darcy- } € 10,000 \text { annually or } \$ 700 \mathrm{~K} U \mathrm{~S} \\
\text { Miss Darcy- } £ 30,000 \text { inheritance } \\
\text { Mr. Bingley- } £ 4,000 \text { annually or } \$ 280,000 \text { US }\end{array}$ & $\begin{array}{l}\text { Rich Capitalist class (1\%): Top-level executives, } \\
\text { celebrities, heirs; income of } \$ 500,000+\text { common. } \\
\text { Educated at the best schools } \\
\text { Professional Upper middle class }(15 \%) \text { : } \\
\text { Professionals usually with graduate degrees or } \\
\text { best in class experience and expertise, earning } \\
\text { approximately } 100 \mathrm{~K}\end{array}$ \\
\hline Third Class: & \\
\hline $\begin{array}{l}\text { Mr. Collins before his inheritance } \\
\text { Fourth Class including Second class of moderate } \\
\text { income: } \\
\text { Mr. Wickham post marriage- }-£ 4,000 \text { inheritance }\end{array}$ & $\begin{array}{l}\text { Lower middle class ( } 30 \%) \text { : Semi-professionals and } \\
\text { craftsmen with a good standard of living. Most } \\
\text { have some college education and are white- } \\
\text { collar. Approximate income range is } 30 \text { to } 80 \mathrm{~K}\end{array}$ \\
\hline $\begin{array}{l}\text { + Lydia's } £ 1000 \text { inheritance }+£ 10 \mathrm{~K} \text { payoff by } \\
\text { Darcy }=£ 15 \mathrm{~K} \text { to invest, } 4 \% \text { return becomes } \\
\text { annual income of } £ 600 \text { or } \$ 42 \mathrm{~K} \text { US } \\
\text { (as well as } £ 1000 \text { debt payoff }+£ 450 \text { to buy his } \\
\text { commission) }\end{array}$ & $\begin{array}{l}\text { Working class ( } 32 \%) \text { : Clerical, pink- and blue- } \\
\text { collar workers, with no more than associates } \\
\text { degree education and limited job security; } \\
\text { common household incomes range from } \$ 16 \text { to } \\
\$ 30 \mathrm{k}\end{array}$ \\
\hline $\begin{array}{l}\text { Fifth Class: } \\
\text { Sixth Class: } \\
\text { Each Bennet girl w/o father- }-£ 40 \text {, or } \$ 2800 \text { US } \\
\text { annually (from } £ 1000 \text { total inheritance) }\end{array}$ & $\begin{array}{l}\text { Working poor (13\%): Service, low-rung clerical } \\
\text { and some blue-collar workers with some high } \\
\text { school education. High economic insecurity and } \\
\text { risk of poverty }\end{array}$ \\
\hline $\begin{array}{l}\text { Wickham }-£ 4,000 \text { inheritance at } 4 \% \text { return } \\
\text { annually }=£ 160 \text { or } \$ 11,200 \text { US }\end{array}$ & $\begin{array}{l}\text { Poor Underclass ( } 12 \%) \text { Those with limited or no } \\
\text { participation in the labor force. Reliant on } \\
\text { government transfers }\end{array}$ \\
\hline $\begin{array}{l}\text { Seventh Class: paupers, vagrants and idle persor } \\
\text { supported by criminal activities }\end{array}$ & \\
\hline
\end{tabular}

The solution is very simple-at least to the mother, Mrs. Bennet, who, like her daughters, will also find herself living on a pittance once her husband dies. She and her daughters will fall from second class as the family of a country gentleman to sixth class working poor. Her lifetime ambition, therefore, is to find suitable husbands for her daughters to preserve their privileged class. The husbands should be rich, and,

PAGE, ANDOH, \& SMITH / DOI: 10.5929/2017.7.2.5 
at the very least, gentlemen. If they belong to the aristocratic class, even better. Mrs. Bennet's frequent nervous agitations are the result of her constant worries over not finding husbands for her daughters and, thus, facing the real possibility of future poverty when Mr. Bennet dies. Indeed, this was the problem facing many young women whose families had no fortune to bequeath to them. Consider the otherwise intelligent Charlotte: How can she marry the obnoxious Mr. Collins, whom her dear friend Elizabeth Bennett had turned down? She does so because she is a "practical/realistic" woman. At twenty-seven, with no fortune or family connections, her prospects are dim. The insufferable Mr. Collins is a good catch; he is clergy, has a good position, is well-connected in society-he is of a higher economic class.

To this day, in both England and America, the two most reliable ways of improving one's economic class are through marriage and inheritance (Chamberlain, 2014). In P\&P, Mr. Wickham personifies social climbing through marriage, successfully transitioning from the $6^{\text {th }}$ class (working poor) to the $4^{\text {th }}$ class (middle class) through cold-blooded seduction to secure a favorable marriage. This also explains Elizabeth's gratitude towards Mr. Darcy-he spent $\$ 80 \mathrm{~K}$ US to save Lydia and the Bennet family from disgrace and scandal.

\section{Balanced Scorecard Approach}

The Balanced Scorecard (BSC) is a quantifiable solution for organizations to overcome the problems associated with focusing solely on financial measures of success (Cardinaels \& Veen-Dirks, 2010). Focusing purely on financial outcomes can cause managers to avoid responsibility and "engage in dysfunctional behaviors to maximize short-term performance at the expense of long-term effectiveness and competitiveness" (Chow \& Van der Stede, p. 2, 2006). Financial measures like "Return on Investment" and "Earnings per Share" are based exclusively on past performance. As such, these results are myopic and give de minimis predictive value regarding the organization's future success. The BSC evaluates an organization's performance using both financial and operative factors (Ghosh \& Mukerjee, 2006).

The BSC perspectives are categorized as follows: financial, learning and growth, internal business process, and customer (Cardinaels \& Veen-Dirks, 2010). The learning and growth perspective focuses not only on employee training, but on mentoring and increased communication effectiveness to allow employees to solve problems more easily. The business process perspective focuses on measuring how well the organization functions internally and if it is producing an effective product. Finally, the customer perspective emphasizes this as a lead indicator of future success despite satisfactory financial success $(\mathrm{BCl}$, 2016). According to the BSC approach, there is a causal connection between the four perspectives that ultimately affects the financial success of an organization while recognizing the needs of a variety of stakeholders (Atkinson, 2006). A scorecard quantifies them and makes them visible, so managers will have a more balanced view of the organization's overall performance, and realize how focusing too much on one perspective will inevitably affect, and at times compromise, the other perspectives $(\mathrm{BCl}, 2016$; Leahy, 2000; Mauboussin, 2014).

In the real world, most organizations that use the BSC approach will tailor it to reflect the needs of the organization and not follow the textbook model of the BSC. The model below is an example of a scorecard a private law practice might use to measure rational goals with numeric scales. The specific scale usedordinal, interval, ratio, semantic differential, etc.-depends on the nature of the feedback management is most interested in. In this case, the lawyer selected a 5-point satisfaction scale ranging from 5 (fully satisfied) to 1 (slightly satisfied) for four major stakeholders (see Table 4, "Balanced Scorecard Model Applied to a Modern-day Law Practice").

PAGE, ANDOH, \& SMITH / DOI: 10.5929/2017.7.2.5 
Table 4

Balanced Scorecard Model Applied to a Modern-day Law Practice

\begin{tabular}{ll}
\hline & Owner Principal \\
\hline Goals & Measures \\
\hline Profitability - (5) & Operating account \\
Reputation - (4) & No. of referrals \\
Case Volume - (5) & Outstanding firm debt \\
Support - (4) & Education; Local and state bar involvement \\
\hline & Clients \\
\hline Goals & Measures \\
\hline Value $-(4)$ & Compare to other Firms \\
Competent Advice - (5) & Outcome of case \\
Fair Billing - (5) & Reg. billing statements \\
Success Rate - (4) & Reputation in Community \\
\hline & State Bar Committee \\
\hline Goals & Measures \\
\hline Licensure - (5) & Attorney registration \\
Membership dues $-(4)$ & Fees due and owing \\
Continuing education - (3) & Registration with bar \\
Pro bono work - (2) & Volunteer in community \\
\hline & Employees \& Interns \\
\hline Goals & Measures \\
\hline Fair wage/benefits - (4) & Market data \\
Training - (3) & Bar sponsored seminars \\
Adequate resources - (3) & Updated software and hardware \\
Supportive work environment - (2) & Employee candor \\
\hline
\end{tabular}

This BSC shows that, like many small firms, this practice satisfies its owners ( 17 pts.) and customers (18 pts.), but at the expense of frustrating and undervaluing its employees (12 pts.). The implication of this imbalance is clear. As this frustration builds, maintaining the superior performance the firm is noted for and retaining key employees who deliver it, become problematic. Note the BSC itself is apolitical and quantitative to minimize the impact of personal agendas, social dynamics, cultural norms, and organizational political factors (Barros \& Wanderley, 2016; Tayler \& B., W., 2013).

\section{Contract Law Shakespearian Style}

Theorist, Jane B. Baron, asserts that "literature [is] a rich source of certain forms of knowledge that the law is either missing entirely or could use a whole lot more of [and] concerns modes of reasoning that are emotional, intuitive, and concrete rather than detached, logical, and abstract; and, most importantly, it concerns the making of truly moral judgments" (Islam, p. 1, 2016). Analyzing Shakespeare's The Merchant of Venice allows the business student to witness the ramifications of entering into business contracts and business ventures without consideration for the various stakeholders affected including the decision- 
makers' own interests. The Merchant of Venice "provides... a unique way of achieving its main purpose, that of jolting students out of their parochialism... and allows for an interesting cultural immersion into the society of Venice in the sixteenth century to learn how the law functioned and to understand the relationship between law and life" (Friedler, p. 1099, 2000).

In the play, Antonio, a Venetian merchant, is approached by his friend Bassanio for a loan that he needed in order to woo his love interest, Portia. Antonio is short on funds, as most of his capital was invested in several trading ships that were not due to arrive back in port for several weeks. Antonio and Bassanio approach Shylock, a Jewish lender who, under Venetian law, was not able to make a living in any other way aside from charging exorbitant interest for his loans. Shylock, being the object of public scorn and ostracism by Antonio and Bassanio based primarily on his faith, is understandably surprised when approached for a loan by those who mocked him. Shylock, nevertheless, agrees to lend three thousand ducats to Bassanio interest-free on the condition that Antonio pledge a pound of his flesh (from close to his heart) as collateral should the loan not be repaid in three months. Overly confident that his ships containing valuable merchandise would arrive well before the due date on the loan, Antonio agrees to Shylocks' terms and the two men execute their contract bond before a notary. After defaulting in the loan, Antonio is brought to court by Shylock who seeks to foreclose on his collateral by taking a pound of Antonio's flesh.

Venice was one of dozens of Mediterranean trading ports; its economy depended on being a port of choice for seagoing merchants. This reputation rested on minimizing risk and providing the physical, legal, and economic infrastructure critical for business. While the law in Venice at the time held Shylock's contract itself to be enforceable, the brutality involved in enforcement undercut the city's reputation for cosmopolitan trade and finance. This led to various provisions guaranteeing reasonable contracts with proportionate penalties-such as the obscure public law Portia discovered that made it illegal for a foreigner to take the life of a citizen lest he forfeit his life or land to the state (Freidler, 2000). Shylock's bloody thirst for revenge is not in keeping with cosmopolitan Venice, and by insisting on barbarism, Venice's Alien Statute humiliates Shylock, who is forced to convert to Christianity and forfeit all of his land (Stretton, 2010).

The model for the BSC can be used to analyze the business of money-lending in The Merchant of Venice. Rational goals can be assessed using a 5-point satisfaction scale ranging from 5 (fully satisfied) to 1 (not satisfied) for three major stakeholders: the customer, the lender and the community. Irrational goals are included to explain low scores, since irrational goals seldom lead to functional outcomes in business. This BSC is summarized in Table 5, "Balanced Scorecard Model Applied to Money-lending in $16^{\text {th }}$ Century Venice."

Shylock's rational professional goals include getting a good interest return on the credit he extends to his clients and establishing himself as a reputable lender in the community. By any measure, Antonio was sub-prime-he offered no collateral but his body. Shylock's decision to make the loan stemmed from an irrational agenda of revenge, returning past emotional abuse with perverse and brutal contingencies for non-payment. Further, when Antonio defaulted on the loan, Bassanio offered Shylock several times what the original loan was worth-a moneylender's dream (Friedler, 2000). Shylock refuses, insisting on collecting his bloody collateral; he emerges a broken and destitute man. Even if Shylock had succeeded in maiming or killing Antonio, the damage to his business reputation and customer base would have been considerable. Further, any rational assessment should have set off alarm bells when a major contract

PAGE, ANDOH, \& SMITH / DOI: 10.5929/2017.7.2.5 
enforcement provision was an egregious violation of cultural norms and resultant public policy (Stretton, 2010).

Table 5

Balanced Scorecard Model Applied to Money-lending in $16^{\text {th }}$ Century Venice

\begin{tabular}{|c|c|}
\hline \multicolumn{2}{|c|}{ Shylock - Owner } \\
\hline Rational Goals & Irrational Goals \\
\hline $\begin{array}{l}\text { Profitability - (1) } \\
\text { Competitiveness - (1) } \\
\text { Sufficient Volume - (1) } \\
\text { Support from Community - (1) }\end{array}$ & $\begin{array}{l}\text { Brutal enforcement provisions } \\
\text { Revenge over profitability } \\
\text { Harsh non-proportional penalties }\end{array}$ \\
\hline \multicolumn{2}{|c|}{ Antonio - Client/Customer } \\
\hline Rational Goals & Irrational Goals \\
\hline $\begin{array}{l}\text { Honor friendship network to build reputation - (5) } \\
\text { Repay loans and financial obligations - (1) } \\
\text { Financial solvency - (1) }\end{array}$ & $\begin{array}{l}\text { Passion over risk assessment } \\
\text { Overconfidence in positive outcomes } \\
\text { Accept irrational, brutal, disproportionate } \\
\text { penalties }\end{array}$ \\
\hline \multicolumn{2}{|c|}{ Regulatory Body - Venice } \\
\hline Rational Goals & Irrational Goals \\
\hline $\begin{array}{l}\text { Preserve integrity of the law of contract - (5) } \\
\text { Regulate business of lending - (5) } \\
\text { Maintain cosmopolitan reputation - (5) }\end{array}$ & $\begin{array}{l}\text { Enforce ubiquitous discriminatory laws } \\
\text { Limit a foreigner's ability to earn a living } \\
\text { Target assets of foreigners for forfeit }\end{array}$ \\
\hline
\end{tabular}

Antonio has rational reasons for supporting his friend and building his reputation, but nothing which justifies the inordinate risks of financial ruin and personal injury. He is blinded by what appears to be his passionate love for Bassanio. He is overly confident that his merchant ships would arrive, despite the very real risks involved (Stretton, 2010). While he is spared from being maimed, he is still bankrupt and financially ruined, dependent on the financial support of others.

The real winner in the play is the city of Venice, whose goals are satisfied without penalty. Today, insurance companies, very much like Shylock, sometimes selfishly insist on a strict interpretation of an insurance policy against their policyholders-which they are legally entitled to do provided they are correct. Insurance contracts are known as contracts of adhesion; the customer either adheres to the terms of the contract or walks away. There is very little negotiation involved in this type of contracting and, for this reason, any ambiguities in contract language will be construed against the entity that drafted the contract (McCallum \& Knapp, 2016). A company can be monetarily penalized by the court for refusing to pay a claim after failing to investigate properly and interpret fairly its own contract (Swisher, 2013). Similarly, Shylock's terms were offered on a "take it or leave it" basis and the ambiguities in the contract were construed against him.

Had either of the major characters (Shylock or Antonio) conducted even a rudimentary BSC analysis with accurate data they would not have been ruined. This play helps us understand the ramifications of making business decisions based on self-interest, passion, jealousy, revenge, and greed, and how assessments of risk and return can become distorted. It also emphasizes how the state often has policy safeguards to

PAGE, ANDOH, \& SMITH / DOI: 10.5929/2017.7.2.5 
protect its interests. The utility of a balanced approach to managerial decision-making, especially when entering into legally-binding contracts, becomes clear.

\section{Implications}

Advocates offer compelling arguments for preparing students for business programs with literature and including literature in business programs. Lessons from literature:

- Make theoretical concepts interesting, rich and memorable

- Develop critical thinking and evaluation skills

- Flesh out details and historical context for a deeper understanding of theory

- Cultivate individual character and integrity

- Link theory and to real-world practice (Michaelson, 2014; Youngkin, 2014)

Unfortunately, there is no consensus on what literature to teach. Youngkin targets literature which bolsters a libertarian paradigm of the businessman as hero, and extols the virtues and power of Ayn Rand's Atlas Shrugged (Youngkin, 2014). Michaelson argues for novels embracing business and government interactions, particularly on a global scale (Michaelson, 2014). Both agree that preferences are unavoidably influenced by cultural and philosophical commitments. Critics go further, suggesting the choice may also be swayed by managerial fad and fashion - trendy "strategies of the month" (Jay, 2001; Michaelson, 2014). Beyond those paradigms are a variety of others, ranging from Marxist critical theory and its literature (i.e. Upton Sinclair's The Jungle) to green sustainability strategies, etc.

Teaching complexity with literature is similar to the study of management itself. There is little consensus in management theory concerning what characterizes an "effective," or "healthy" organization. Even when conceptions of the ideal organization are identified and developed, they often tend to be more controversial than the problems they addressed. This principle is carried to its logical extremes in fields such as mental health and social policy, where consensus is fleeting and where many opinions or perspectives can be advanced and rationally defended. Overwhelmed by uncertainty and confused by paradox, managers and analysts in these areas often adopt a "remedial," or problem-oriented approach towards understanding and changing these divergent phenomena.

The characteristics of the strategy support and encourage the analyst to identify situations or ills from which to move away rather than goals toward which to move. Even short term goals are defined largely in terms of reducing some observed ill rather than in terms of a known objective of another sort. Policy aims at suppressing vice even though virtue cannot be defined, let alone concretized as a goal; at attending to mental illness even though we are not sure what attitudes and behaviors are most healthy; ... at eliminating inequities in the tax structure even though we do not agree on equity [etc.]. (Braybrooke, \& Lindbloom, 1963, p.102)

Given disagreement on content, perhaps the focus should be on process (Weick, 1979, 1995; Weick, Sutcliffe, \& Obstfeld, 2005). Weick notes that scientific inquiry into management is based on the assumption that while there may be many research approaches to management, and while organizations are often characterized by unique problems, all of these paths will eventually lead to an understanding of the nature of management, and the best, most effective way to manage.

PAGE, ANDOH, \& SMITH / DOI: 10.5929/2017.7.2.5 
These two connected themata of unlimited outer accessibility and delimited inner meaning can be vaguely depicted by the device of a maze having in its outer walls innumerable entrances, through each of which one can hopefully reach, sooner or later, the one mystery which lies at the center... But another possibility has suggested itself more and more insistently; that at the innermost chamber of the maze one would find nothing... (Holton, 1965, p. xxiii)

Given a rapidly changing, discontinuous world, the center of the management maze may be empty. The true meaning and nature of effective management lies not in the act of discovery but in the process of discovering. The maze is the meaning, and how managers decide to negotiate through that maze-the set of skills, values and preferences they cultivate-determines both understanding and effectiveness. The key becomes to keep learning, keep trying, keep adapting, and keep hoping that some emergent process proves satisfactory (Christensen, 2013; Quinn, 1988, 2015; Senge, 2006). From this perspective, teaching complexity builds a sort of mental toolkit graduates can use whenever they find themselves immersed in paradox and chaos. Repeated exposure and exploration of the usefulness of these analytical tools in a variety of contexts seems essential for students to recognize their worth and apply them to their professions. The goal is to unlock the creativity and imagination needed to adapt to a rapidly changing world and rapidly, iteratively learn. Otherwise graduates are intellectually stunted:

Yet I have seen that business education treats young men and women precisely as if they were destined to be at shop and to talk shop all day. Even the liberal arts have been influenced by this slavish and utilitarian view of human nature. We prepare young people to become cows and mules rather than men and women. We expend great energy and dedicate vast sums of money toward directing all of youth's energy into the pursuit of a career. We accord professionalism and careerism a standing that far outshadows learning the human condition and cultivating the moral imagination. My guild has sent out into society far too many souls whose imaginations are starved, who do not know what to do with themselves when they are not at work other than to feed appetites that will never be satisfied and to pursue pleasures that will never bring happiness. (Guroian, 2002)

The academy has already recognized that integrative approaches such as interdisciplinarity and multidisciplinarity result in many positive proximate outcomes, such as retention of learning and student satisfaction, as well as distal outcomes such as transfer of learning and job placement (Kuh, 2008). Literature may prove to be a pre-business program power tool-embedding this exploration in literature adds impact to the process by engaging students on a personal, emotional level. It introduces key techniques and models to analyze complexity before the students engage in higher-level business courses where they will be of critical importance. Further, powerful prose increases the likelihood that such lessons about paradox and complexity will be retained and transferred. Above all, students will have had the opportunity to confront and hopefully expand their comfort with high levels of uncertainty, complexity and paradox in real-world (though fictional) contexts. This recommends further exploration and experimentation.

\section{References}

AACU National Panel. 2002. Greater expectations: A new vision for learning as a nation goes to college. Washington, DC: Association of American Colleges and Universities.

Adler, P. S., \& Borys, B. (1996). Two types of bureaucracy: Enabling and coercive. Administrative Science Quarterly, 61-89.

PAGE, ANDOH, \& SMITH / DOI: 10.5929/2017.7.2.5 
American Society for Quality [ASQ] (2015). Stakeholder analysis. Retrieved from http://asq.org/service/body-of-knowledge/tools-stakeholder-analysis

Andriopoulos, C., \& Lewis, M. W. (2009). Exploitation exploration tensions and organizational ambidexterity: Managing paradoxes of innovation. Organization Science, 20, 696-717.

Atkinson, H., (2006) Strategy implementation: a role for the balanced scorecard? Management Decision, 44(10), 1441-1460.

Association to Advance Collegiate Schools of Business [AACSB]. (2015). A new vision for business education. Retrieved from: http://www.aacsb.edu/vision ?utm source =HighRoads \%20Solutions\&amp;utm medium=Email\&amp;utm campaign=HighRoads\%20All\%2

Association to Advance Collegiate Schools of Business [AACSB]. (2005). Eligibility procedures and standards for business school accreditation. St. Louis, MO: AACSB International.

Atwater, J. B., Kannan, V. R., \& Stephens, A. A. (2008). Cultivating systemic thinking in the next generation of business leaders. Academy of Management Learning \& Education, 7(1), 9-25.

Badaracco, J. (2006). Questions of character: Illuminating the heart of leadership through literature. Harvard Business Press.

Balanced Scorecard Institute [BSI] (2016). Balanced Scorecard Basics. Retrieved from: https://balancedscorecard.org/Resources/About-the-Balanced-Scorecard

Barros, O. J., \& Wanderley, C. D. (2016). Adaptation of the balanced scorecard: Case study in a fuel distribution company. Revista Contabilidade \& Finanças, 27(72), 320-333. doi:10.1590/1808057x201602200

Battilana, J., \& Casciaro, T. (2012). Change agents, networks, and institutions: A contingency theory of organizational change. Academy of Management Journal, 55(2), 381-398.

Beech, N., Burns, H., de Caestecker, L., MacIntosh, R., \& MacLean, D. (2004). Paradox as invitation to act in problematic change situations. Human Relations, 57, 1313-1332.

Bechara, J., \& Van de Ven, A. H. (2011). Triangulating philosophies of science to understand complex organizational and managerial problems. Research in the Sociology of Organizations, 32, 343-364.

Biriotti M. (2013). But what can literature teach us about doing business better? The Guardian. Retrieved from: http://www.theguardian.com/sustainable-business/blog/what-can-literature-teachabout-business

Braybrooke, D., \& Lindbloom, C. E. (1963). A strategy of decision. New York: Free Press.

Calvo, G. A. (1988). Costly trade Liberalizations: Durable Goods and capital Mobility, IMF Staff Papers, 35(3) 461- 473.

Cameron, K.S. (1986). Effectiveness as paradox: Consensus and conflict in conceptions of organizational effectiveness. Management Science, 32(5), 539-553.

Cardinaels, E., \& Veen-Dirks, P. M. (2010). Financial versus non-financial information: The impact of information organization and presentation in a Balanced Scorecard. Accounting, Organizations and Society, 35(6), 565-578. doi:10.1016/j.aos.2010.05.003 
Carr, J. C., \& Blettner, D. P. (2010). Cognitive control bias and decision-making in context. Frontiers of Entrepreneurship Research: 30(6), 17-32.

Chamberlain, S. (2014). The economics of Jane Austen. The Atlantic. Retrieved from: http://www.theatlantic.com/business/archive/2014/08/the-economics-of-jane-austen/375486/

Chew, E.B. \& McInnis-Bowers, C. (2004). Blending liberal arts and business education. Liberal Education, 99(1), 56-63.

Chow, C. W., \& Van der Stede, W. A. (2006). The use and usefulness of nonfinancial performance measures. Management Accounting Quarterly, 7(3), 1-8. Retrieved from: http://s3 .amazonaws.com/academia.edu.documents/43669615/2006maq spring vanderstedepdf.pdf?AWSAccessKeyld=AKIAJ56TQJRTWSMTNPEA\&

Christensen, C. (2013). The innovator's dilemma: when new technologies cause great firms to fail. Harvard Business Review Press.

Cummings, T., \& Worley, C. (2014). Organization development and change. Cengage learning.

Datar, S. M., Garvin, D. A., \& Cullen, P. G. (2011). Rethinking the MBA: Business education at a crossroads. Journal of Management Development, 30(5), 451-462.

Davies, A., Fidler, D., \& Gorbis, M. (2011). Future work skills 2020. San Francisco: Institute for the Future for the University of Phoenix Research Institute

Day, G. S. (2012). Aligning the organization with the market. Marketing Science Institute Report, 5(3).

Drummond, H. (2014). Escalation of commitment: When to stay the course? The Academy of Management Perspectives, 28(4), 430-446.

Ellingsen, T., \& Johannesson, M. (2008). Pride and prejudice: The human side of incentive theory. The American Economic Review, 98(3), 990-1008.

Fischer, K. (2013). A college degree sorts job applicants, but employers wish it meant more. The Chronicle of Higher Education. Retrieved from: http://chronicle.com/article/The-EmploymentMismatch/137625/\#id=overview

Friedler, E., Z. (2000). Shakespeare's contribution to the teaching of comparative law - Some reflections on The Merchant of Venice, LA Law Review, 60.

Gandz, J., \& Hayes, N. (1988). Teaching business ethics through case study. Journal of Business Ethics, 7(9), 657-669.

Gharajedaghi, J. (2011). Systems thinking: Managing chaos and complexity: A platform for designing business architecture. Elsevier.

Ghosh, S., \& Mukherjee, S. (2006). Measurement of corporate performance through balanced scorecard: an overview. Vidyasagar University Journal of Commerce, 11, 60-70. Retrieved from: https://pdfs.semanticscholar.org/9b71/998 192ffe123f35e2d3b0467014f501e6726.pdf.

Gimpl, M. L., \& Dakin, S. R. (1984). Management and magic. California Management Review, pp. 125-137.

Grey, C. (2004). Reinventing business school: The contribution of critical management education. Academy of Management Learning and Education, 3(2), 178-186.

PAGE, ANDOH, \& SMITH / DOI: 10.5929/2017.7.2.5 
Guroian, V. (2002). Why Should Businessmen Read Great Literature? Religion \& Liberty, 12(4) Retrieved from: $\quad$ http://www.acton.org/pub/religion-liberty/volume-12-number-4/why-shouldbusinessmen-read-great-literature

Hart Research. (2013). It takes more than a major: employer priorities for college learning and student success. Washington, DC: The Association of American Colleges and Universities.

Helprin, M. (1988). The canon under siege. New Criterion 7(1), 36.

Holton, G. (1965). Introduction. Daedalus, 94, v-xxix.

Islam, N. (2016). Shakespeare and the Law: A Critical Analysis. Retrieved from: http://trinitycollegelawreview.org/shakespeare-and-the-law-a-critical-analysis/

Jackson, B. (2001) Management gurus and management fashion. New York: Routledge.

Jay, J. (2013). Navigating paradox as a mechanism of change and innovation in hybrid organizations. Academy of Management Journal, 56(1), 137-159.

Kathuria, R., Joshi, M. P., \& Porth, S. J. (2007). Organizational alignment and performance: past, present and future. Management Decision, 45(3), 503-517.

Kaplan, R. S., \& Norton, D. P. (1996). The balanced scorecard: translating strategy into action. Harvard Business Press.

Kuh, G.D. (2008). High-impact educational practices: What they are, who has access to them, and why they matter. Washington, DC: AAC\&U

Langer, E.J. (1975). The illusion of control. Journal of Personality and Personal Psychology, 32(2), 311-328.

Leahy, T. (2000). Tailoring the Balanced Scorecard. Retrieved from: http://businessfinancemag .com/bpm/tailoring-balanced-scorecard

Leddy, C. (2013). Truth in fiction. Harvard Gazette. Retrieved from: http://news .harvard.edu/gazette/story/2013/08/truth-in-fiction/

Lin, Y. P. (2015). Association to Advance Collegiate Schools of Business Accreditation: A Long-Term Perspective. Business Education \& Accreditation, 7(1), 25.

Mauboussin, M. J. (2014). The True Measures of Success. Retrieved from: https://hbr.org/2012/10/thetrue-measures-of-success

McCallum, B. T., \& Knapp, M. C. (2016). Coping with catastrophes: Business interruption insurance claims. CPA Journal.

Meyer, J., \& Land, R. (2013). Overcoming barriers to student understanding: Threshold concepts and troublesome knowledge. Routledge.

Michaelson, C. (2014). Literature and the canonical values of capitalism. In D. Koehn \& D. Elm (Eds.), Aesthetics and Business Ethics (37-50). Dordrecht: Springer.

Miles, R.E., Snow, C.C., Meyer, A.D., and Coleman, Jr. H.J. (1978). Organizational strategy, structure, and process, The Academy of Management Review, 3, 546-562.

PAGE, ANDOH, \& SMITH / DOI: 10.5929/2017.7.2.5 
Moskal, P., Ellis, T., \& Keon, T. (2008). Summary of assessment in higher education and the management of student-learning data. Academy of Management Learning \& Education, 7(2), 269-278.

Niven, P. R. (2014). Balanced scorecard evolution: A dynamic approach to strategy execution. John Wiley \& Sons.

Peter, T., \& Waterman, R. (1982). In search of excellence. Lessons from Americans best running companies. New York: Harper \& Row.

Pffefer, J., \& Fong, C. (2002). The end of business schools? Less success than meets the eye. Academy of Management Learning and Education, 1(1), 78-95.

Plastrik, P., Taylor, M., \& Cleveland, J. (2014). Connecting to change the world: Harnessing the power of Networks for Social Impact. Island Press.

Quinn, R. E. , Bright, D., Faerman, S. R., Thompson, M. P., \& McGrath, M. R. (2015). Becoming a master manager: A competing values approach ( $6^{\text {th }}$ ed.). Hoboken, NJ: Wiley.

Quinn, R.E. (1988). Beyond Rational Management: Mastering the Paradoxes and Competing Demands of High Performance. San Francisco: Jossey-Bass.

Quinn, R.E., \& Rohrbaugh, J. (1983). A spatial model of effectiveness criteria: Towards a competing values approach to organizational analysis. Management Science, 29, 363-377.

Safon, V. (2007). Factors That Influence Recruiter's Choice of B-Schools. Academy of Management Learning and Education, 6(2), 217-233.

Schumacher, E.F. (1977). A Guide for the Perplexed. New York: Harper and Row.

Senge, P. M. (2006). The Fifth Discipline: The Art \& Practice of The Learning Organization. New York: Doubleday

Seybolt, J. (2004). Managing in tumultuous times. BizEd, 3(3), 39-43.

Shepard, J. M., Goldsby, M. G., \& Gerde, V. W. (1997). Teaching business ethics through literature. Teaching Business Ethics, 1(1), 33-51.

Slaatte, H.A. (1968). The Pertinence of the Paradox. New York: Humanities Press.

Smith, W. K., \& Lewis, M. W. (2011). Toward a theory of paradox: A dynamic equilibrium model of organizing. Academy of Management Review, 36(2), 381-403.

Smith, T. W., \& Colby, S. A. (2007). Teaching for deep learning. The Clearing House: A Journal of Educational Strategies, Issues and Ideas, 80(5), 205-210.

Solomon, R. (1976). The passions. New York: Anchor Press.

Sterman, J. D. (2000). Business dynamics: Systems thinking and modeling for a complex world. New York: Irwin.

Steinbeck, J., \& Ricketts, E. F. (1951). The log from the Sea of Cortez: The narrative portion of the book, Sea of Cortez. New York: Viking Press.

Stretton, T. Contract, debt litigation and Shakespeare's The Merchant of Venice. Retrieved from: http://www.austlii.edu.au/au/journals/AdelLawRw/2010/7.pdf

PAGE, ANDOH, \& SMITH / DOI: 10.5929/2017.7.2.5 
Swisher, P. N. (2013). Why won't my homeowners insurance cover my loss: Reassessing property insurance concurrent causation coverage disputes. Tul. L. Rev., 88, 515.

Tayler, B. W. (2013). Is your strategy evaluation biased? The balanced scorecard may be the cause-and the cure. Strategic Finance, 95(11), 27-34.

Thompson, T. A., \& Purdy, J. M. (2009). When a good idea isn't enough: Curricular innovation as a political process. Academy of Management Learning \& Education, 8(2), 188-207.

Tugend, A. (2013). What It Takes to Make New College Graduates Employable. New York Times. Retrieved from: http://www.nytimes.com/2013/06/29/your-money/a-quest-to-make-college-graduates employable.html

Weick, K. E., Sutcliffe, K. M., \& Obstfeld, D. (2005). Organizing and the process of sensemaking. Organization Science, 16(4), 409-421.

Weick, K. E. (1995). Sensemaking in organizations (Vol. 3). Sage.

Weick, K. (1979). The social psychology of organizing ( $2^{\text {nd }}$ ed.). Reading, MA: Addison-Wesley.

Wilden, R., Gudergan, S. P., Nielsen, B. B., \& Lings, I. (2013). Dynamic capabilities and performance: strategy, structure and environment. Long Range Planning, 46(1), 72-96.

Younkins, E. W. (2014). Exploring capitalist fiction. In Business through Literature and Film (331-334). Lanham, MD: Lexington Book.

About the Authors

Robert A. Page (Pager1@southernct.edu) is a Professor of Management at Southern Connecticut State University. He is on the editorial boards of a number of business research journals and his publications have appeared recently in the Journal of International Business Disciplines, Journal of Academic and Business Ethics, Quarterly Review of Business Disciplines, and the International Journal of Interdisciplinary Research, among many others. His research interests include entrepreneurship, organizational change and leadership, both nationally and internationally.

Samuel K. Andoh (Andos1@southernct.edu) is a Professor of Economics and the director of the MBA program at Southern Connecticut State University. Some of his recent publications have appeared in Applied Economics, Applied Economics Letters, Financial Review and African Development Review. He has worked on the marginal cost section of the Connecticut Results First Cost Benefit Analysis which was funded by the Pew Center on the States and the MacArthur Foundation. Professor Andoh's research interests include development and finance, money and banking, and monetary policy.

Robert A. Smith (Smithjrr1@southernct.edu) is an Assistant Professor of Management at Southern Connecticut State University. As a licensed attorney engaged in the practice of law, Professor Smith primarily teaches business law related courses. He has recently published in the Quarterly Review of Business Disciplines and Competition Forum journals. He also co-authored a legal textbook entitled Bankruptcy Law \& Practice for Pearson Education, with Grace A. Luppino. His research interests include business education, contract law, employment law, and bankruptcy law.

PAGE, ANDOH, \& SMITH / DOI: 10.5929/2017.7.2.5 